\title{
SISTEM PENGENDALI PERALATAN ELEKTRONIK DALAM RUMAH SECARA OTOMATIS MENGGUNAKAN SENSOR PIR, SENSOR LM35, DAN SENSOR LDR
}

Eka Desyantoro $^{1)}$, Adian Fatchur Rochim ${ }^{2)}$, Kurniawan Teguh Martono ${ }^{2)}$

Program Studi Teknik Sistem Komputer, Fakultas Teknik, Universitas Diponegoro, Jln. Prof. Sudharto, Tembalang, Semarang, Indonesia email : desyantoro.ekades@gmail.com

\begin{abstract}
ABSTRAK
Listrik merupakan hal yang sangat penting di kehidupan kita. Setiap pekerjaan kita pasti dibantu dengan adanya listrik. Mulai dari penerangan hingga pengaturan suhu ruangan pun semuanya dibantu oleh listrik. Ketergantungan manusia terhadap listrik ini menimbulkan kebiasaan buruk. Banyak orang yang terkadang membiarkan suatu peralatan elektronik hidup pada saat tidak dibutuhkan. Terjadi suatu permasalahan untuk menciptakan suatu desain sistem embedded untuk mengendalikan peralatan elektronik dalam rumah secara otomatis.

Makalah ini membahas tentang perancangan sistem pengendali peralatan elektronik dalam rumah secara otomatis. Sistem terdiri dari sensor PIR yang berfungsi untuk mendeteksi objek bergerak (manusia), sensor LM35 yang berfungsi untuk mendeteksi suhu, dan sensor LDR berfungsi sebagai sensor cahaya. Mikrokontroller ATMegal6 sebagai pengendali jalannya sistem dari pembacaan sensor, menampilkan data sensor pada LCD dan mengatur kontak relay untuk menghidup dan mematikan listrik.

Sistem pengendali peralatan elektronik dalam rumah secara otomatis menunjukan sensor LDR dapat membedakan gelap dan terang, sensor suhu LM35 dapat mendeteksi suhu dalam ruangan dengan toleransi kesalahan pembacaan kurang lebih $2^{\circ}$ Celcius, dan sensor PIR dapat mendeteksi pergerakan manusia sejauh 5 meter.
\end{abstract}

Kata Kunci : listrik, otomatis, mikrokontroller, sensor PIR, sensor LM35, sensor LDR

\section{PENDAHULUAN}

1.1 Latar Belakang

Listrik merupakan hal yang sangat penting di kehidupan kita. Setiap pekerjaan kita pasti dibantu dengan adanya listrik. Mulai dari penerangan hingga pengaturan suhu ruangan pun semuanya dibantu oleh listrik. Ketergantungan manusia terhadap listrik ini menimbulkan kebiasaan buruk. Banyak orang yang terkadang membiarkan suatu perangkat hidup pada saat tidak dibutuhkan. Contohnya adalah lupa mematikan TV saat sedang pergi, menghidupkan pendingin ruangan saat keadaan rumah kosong, menghidupkan lampu di siang hari, dan lain-lain. Hal ini tentu saja mengakibatkan pemborosan listrik.

Guna mengatasi masalah pemborosan listrik perlu peran serta dari masyarakat secara langsung yaitu dengan cara menghemat penggunaan listrik mulai dari hal kecil, misalnya tidak menyalakan lampu pada siang hari, mematikan segala peralatan elektronik dalam rumah yang membutuhkan daya listrik saat tidak ada orang dalam rumah dan lain sebagainya. Akan tetapi dalam melakukan penghematan listrik dari hal kecil tersebut terkadang masyarakat suka lupa atau malas untuk melakukannya.

Kemajuan teknologi sekarang dapat membantu memudahkan manusia khususnya untuk mengendalikan hidup dan matinya listrik dengan cara sistem otomatisisasi untuk menghidupkan dan mematikan peralatan elektronik dalam rumah yang membutuhkan sumber daya listrik menggunakan sensor cahaya, sensor suhu, dan sensor pendeteksi keberadaan manusia.

1.2 Tujuan

1. Merancang desain sistem embedded yang dapat mengendalikan peralatan elektronik di dalam rumah secara otomatis dengan memanfaatkan sensor PIR, sensor LM35, sensor LDR dan limit switch.

2. Mengimplementasikan hasil rancangan desain sistem embedded tersebut dalam bentuk purwarupa.

3. Menguji hasil rancangan untuk mengendalikan peralatan elekronik dalam rumah secara otomatis.

1.3 Batasan masalah

Batasan masalah yang dibahas pada tugas akhir ini:

1. Pembuatan sistem embedded bertujuan untuk menghidup dan mematikan peralatan elektronik dalam rumah secara otomatis.

2. Pembuatan sistem menggunakan sensor PIR, sensor $L M 35$, sensor $L D R$ dan limit switch untuk mengetahui kondisi ruangan dalam rumah, serta relay sebagai output untuk mengatur tegangan $\mathrm{AC}$ yang terhubung ke peralatan elektronik.

3. Sensor PIR (Passive Infrared Receiver) hanya digunakan untuk mendeteksi gerakan manusia.

4. Sensor LDR hanya digunakan untuk mendeteksi keadaan cahaya dalam ruangan dalam kondisi gelap atau terang. 
5. Hasil dari sistem ini berupa purwarupa perangkat yang dapat mengendalikan perangkat elektronik rumah secara otomatis.

\section{LANDASAN TEORI}

\subsection{Listrik}

Menurut jenis arusnya, sistem tenaga listrik dikenal dengan sistem arus bolak-balik (AC) dan sistem arus searah (DC). Pada sistem AC, penaikkan dan penurunan tegangan, medan magnet putarnya mudah dilakukan. Maka berdasarkan kemudahan tersebut, hampir di seluruh dunia menggunakan sistem tenaga listrik AC, walaupun sistem DC juga mulai dikembangkan dengan pertimbangan-pertimbangan tertentu.

Listrik merupakan bentuk energi yang paling cocok dan nyaman bagi manusia modern. Makin bertambahnya konsumsi listrik per kapita di seluruh dunia menunjukkan kenaikkan standar kehidupan manusia. Dengan pertumbuhan permintaan tenaga listrik, maka harus direncanakan pembangunan pusatpusat listrik baru, atau menciptakan bentuk-bentuk energi baru untuk mendukungnya, apabila kapasitas pusat listrik yang ada pada saat ini tidak cukup mendukungnya. Pembangunan tenaga listrik memerlukan dana yang besar dan waktu yang lama, selain juga pertimbangan-pertimbangan politis, ketersediaan bahan bakar dan sumber daya manusianya. ${ }^{[6]}$

\subsection{Mikrokontroller ATMega16}

Mikrokontroler adalah sebuah sistem komputer lengkap dalam satu serpih (chip). Mikrokontroler lebih dari sekedar sebuah mikroprosesor karena sudah terdapat atau berisikan ROM (Read-Only Memory), RAM (Read-Write Memory), beberapa port masukan maupun keluaran, dan beberapa peripheral seperti pencacah/pewaktu, ADC (Analog to Digital converter), DAC (Digital to Analog converter) dan serial komunikasi. Gambar 1 menunjukan konfigurasi pin ATMega16. ${ }^{[2]}$

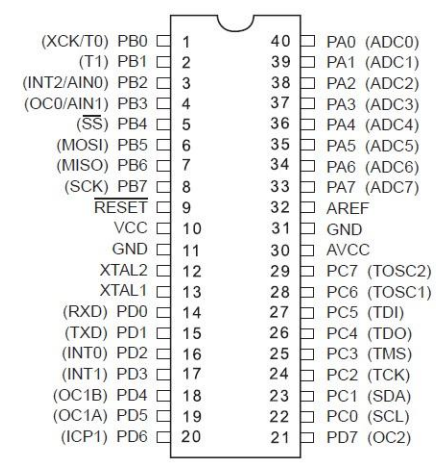

Gambar 1 Konfigurasi pin ATMega16 ${ }^{[2]}$

\subsection{Sensor}

\subsubsection{Sensor PIR}

Sensor Passive Infrared Receiver (PIR), sensor ini merupakan sensor berbasis infrared namun tidak sama dengan IR LED dan fototransistor. Sensor PIR merespon energi dari pancaran infrared pasif yang dimiliki oleh setiap benda yang terdeteksi olehnya. Salah satu benda yang memiliki pancaran infrared pasif adalah tubuh manusia. Energi panas yang dipancarkan oleh benda dengan suhu diatas nol mutlak akan dapat ditangkap oleh sensor tersebut. Bagian-bagian dari PIR adalah Fresnel Lens, IR Filter, Pyroelectric sensor, amplifier, dan comparator. Gambar 2 menunjukan bentuk fisik sensor PIR. ${ }^{[12]}$

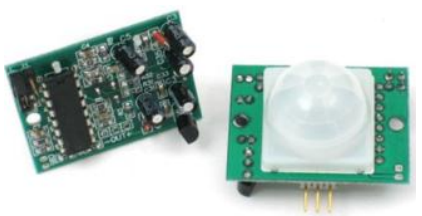

Gambar 2 Bentuk Fisik Passive Infra Red ${ }^{[12]}$

\subsubsection{Sensor LM35}

Sensor LM35 adalah sensor suhu yang terkemas dalam bentuk Integrated Circuit. Sensor suhu LM35 yang mempunyai 3 pin, pin 1 berfungsi sebagai sumber tegangan kerja dari LM35, pin 2 atau kaki tengah digunakan sebagai tegangan keluaran atau Vout dengan jangkauan kerja dari 0 Volt sampai dengan 1,5 Volt dengan tegangan operasi sensor LM35 yang dapat digunakan antara 4 Volt sampai 30 Volt, pin 3 berfungsi sebagai ground. Gambar 3 menunjukan gambar sensor LM35.

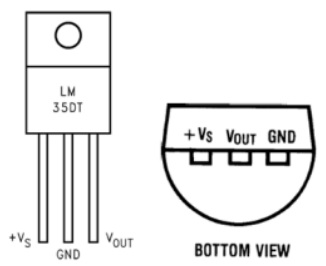

Gambar 3 Sensor LM35 ${ }^{[10]}$

Sensor ini mempunyai koefisien sebesar 10 $\mathrm{mV} /{ }^{\circ} \mathrm{C}$ yang berarti bahwa setiap kenaikan suhu $1{ }^{\circ} \mathrm{C}$ maka akan terjadi kenaikan tegangan sebesar $10 \mathrm{mV} .{ }^{[10]}$

\subsubsection{Sensor LDR}

LDR (Light Dependent Resistor) merupakan sensor cahaya yang dibuat dari bahan semikonduktor beresistansi tinggi yang tidak dilindungi dari cahaya.

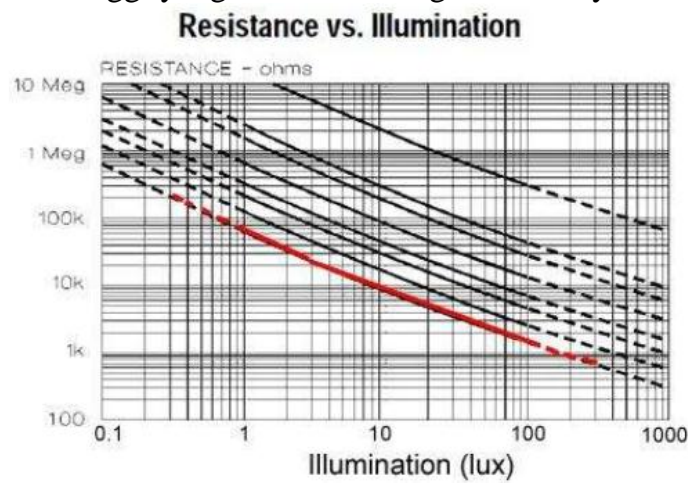

Gambar 4 Grafik Perbandingan Antara

Resistansi LDR dengan Kadar Cahaya ${ }^{[5]}$

Dari gambar 4 dapat diketahui bahwa semakin terang cahaya yang mengenai LDR, maka resistansinya akan semakin mengecil. ${ }^{[5]}$ 


\subsection{Limit Switch}

Suatu sensor memberitahukan kepada kontroler jika suatu bagian yang bergerak berada pada posisi yang tepat. Limit switch adalah salah satu contoh dari sensor proximity. Limit switch adalah suatu tombol atau katup atau indikator mekanik yang diletakkan pada suatu tempat yang digerakkan ketika suatu bagian mekanik berada di ujung sesuai dengan pergerakan yang diinginkan, Sebagai contoh, dalam pembuka pintu otomatis garasi semua kontroler harus mengetahui apakah pintu terbuka atau tertutup sepenuhnya, Limit switch dapat mendeteksi kedua kondisi ini.

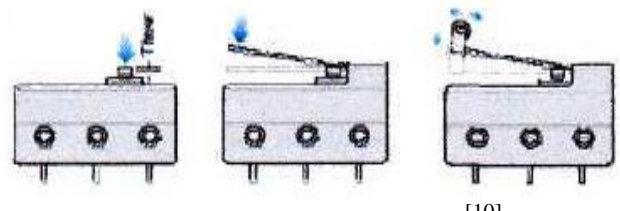

Gambar 5 limit switch ${ }^{[10]}$

Gambar 5 menunjukkan beberapa contoh limit switch. Limit switch sangat berperan untuk banyak aplikasi. ${ }^{[10]}$

\subsection{Relay}

Relay adalah saklar yang dioperasikan secara elektrik. Arus yang mengalir melalui kumparan relay menciptakan medan magnet yang menarik tuas dan merubah kontak saklar. ${ }^{[5]}$

\section{$2.6 \mathrm{LCD}$}

LCD adalah sebuah display dot matriks yang difungsikan untuk menampilkan tulisan berupa angka atau huruf sesuai dengan yang diinginkan. Gambar 6 menunujukan modul LCD $16 \times 2 .{ }^{[4]}$

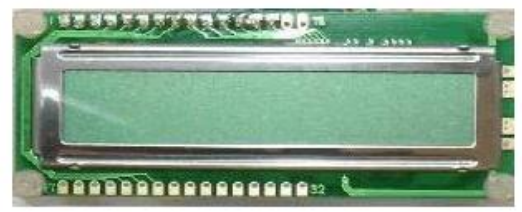

Gambar 6 modul LCD 16x $2^{[4]}$

\subsection{Sekering (Fuse)}

Fungsi Sekering adalah suatu alat yang digunakan sebagai pengaman dalam suatu rangkaian listrik apabila terjadi kelebihan muatan listrik atau suatu hubungan arus pendek. Cara kerjanya apabila terjadi kelebihan muatan listrik atau terjadi hubungan arus pendek, maka secara otomatis sekering tersebut akan memutuskan aliran listrik dan tidak akan menyebabkan kerusakan pada komponen yang lain. ${ }^{[7]}$

\subsection{ADC (Analog to Digital Converter)}

ADC adalah sebutan untuk rangkaian pengubah input sinyal analog (sinyal kontinu terhadap waktu) menjadi output sinyal digital (sinyal diskret atau terkuantisasi terhadap waktu). Pada Gambar 7 disajikan perbedaan sinyal digital pada gambar sebelah kiri dan sinyal analog pada gambar sebelah kanan. ${ }^{[2]}$
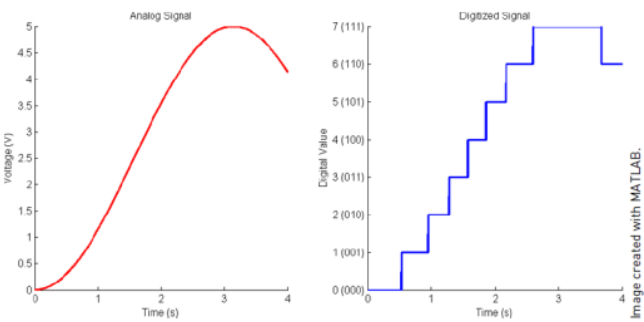

Gambar 7 Sinyal analog dan sinyal digital ${ }^{[8]}$

\section{PERANCANGAN SISTEM}

\subsection{Perancangan Perangkat Keras}

Perancangan perangkat keras pada sistem pengendali peralatan elektronik dalam rumah secara otomatis ini menggunakan beberapa macam periperal yang terhubung langsung dengan mikrokontroler sebagai pusat pengolahan data yang berkaitan dengan input atau output sistem. Terdapat periperal yang digunakan sebagai input sistem yaitu sensor $P I R$, sensor LM35, sensor $L D R$, dan limit switch. Serta periperal sebagai output yaitu LCD 16x2 dan relay.

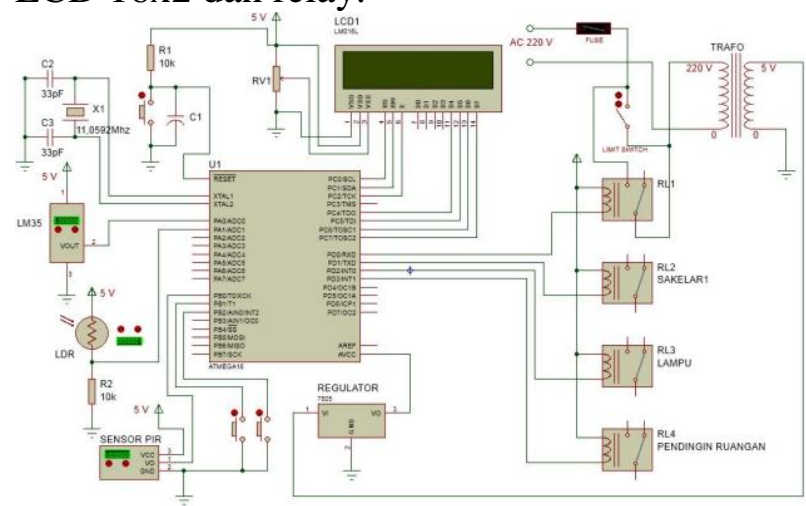

Gambar 8 skematik rangkaian sistem pengendali peralatan elektronik dalam rumah secara otomatis menggunakan sensor pir, lm35 dan $l d r$

Gambar 8 menunjukan skematik rangkaian dari sistem dimana dalam sistem minimum ATMega16 dilengkapi dengan rangkaian reset dan oscillator.

\subsection{Perancangan Perangkat Lunak}

Perancangan perangkat lunak merupakan perancangan program yang dibutuhkan oleh mikrokontroller ATMega16 untuk dapat mengendalikan output relay sesuai data masukan dari sensor PIR, sensor $L M 35$, dan sensor $L D R$ serta dapat menampilkan nilai data dari ketiga sensor tersebut di LCD.

Perancangan dan pembuatan perangkat lunak secara umum dapat dijelaskan pada diagram alir proses di gambar 9 . 

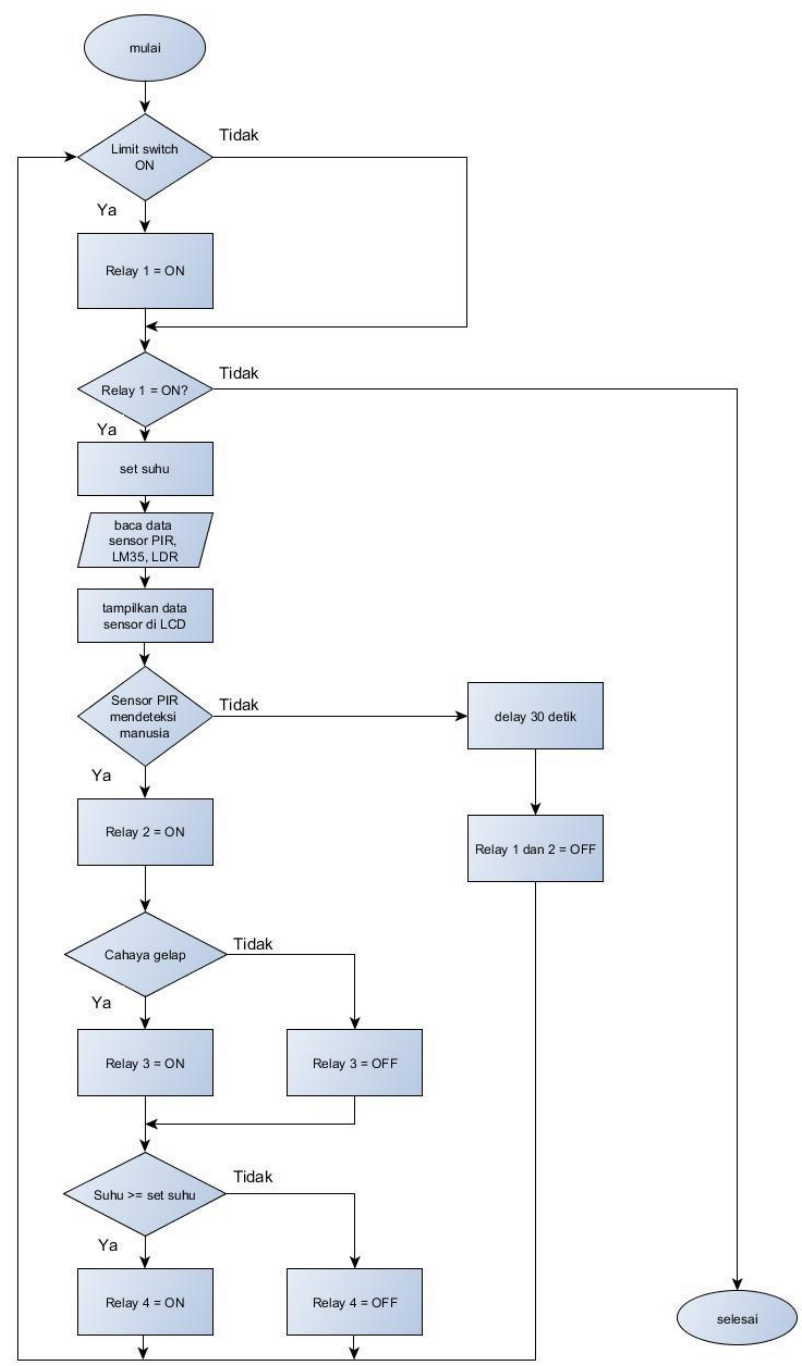

Gambar 9 Diagram Alir Proses Perancangan Perangkat Lunak

\section{IMPLEMENTASI DAN PENGUJIAN}

\subsection{IMPLEMENTASI PERANGKAT KERAS DAN PERANGKAT LUNAK}

Implementasi sistem terdiri dari keseluruhan perangkat keras yang dirangkai untuk proses sistem pengendali peralatan elektronik dalam rumah secara otomatis. Sistem yang terdapat pada gambar 4.1 terdiri dari sistem minimum ATMega16, perangkat masukan yang berupa sensor $P I R$, sensor $L M 35$, sensor $L D R$ dan limit switch, LCD 16x2 berfungsi untuk menampilkan nilai data dari sensor, relay untuk mengendalikan peralatan elektronik.

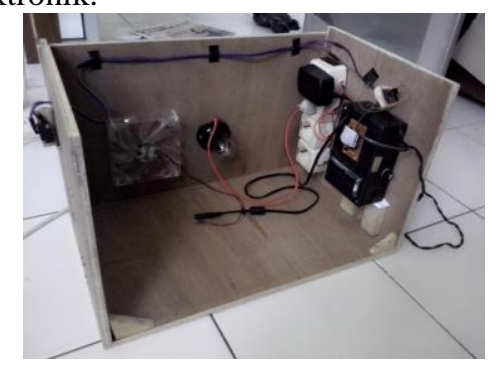

Gambar 10 sistem pengendali peralatan elektronik dalam rumah secara otomatis

\subsection{PENGUJIAN SUBSISTEM LCD $16 \mathrm{X} 2$}

Pengujian subsistem LCD 16x2 dilakukan dengan memprogram untuk menampilkan tulisan atau karakter pada LCD, kemudian mencocokan dengan tampilan karakter pada layar LCD. Berikut merupakan listing program untuk menampilkan karakter di LCD :

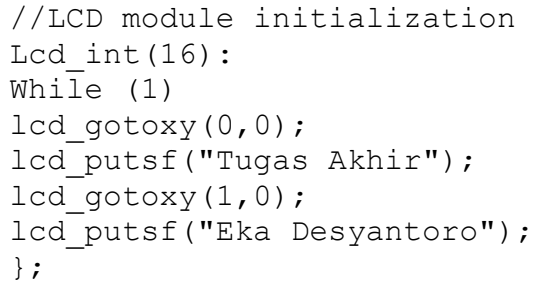

Pada program tersebut dikompilasi dan diunggah ke mikrokontroller, maka tampilan LCD akan seperti gambar 11 berikut.

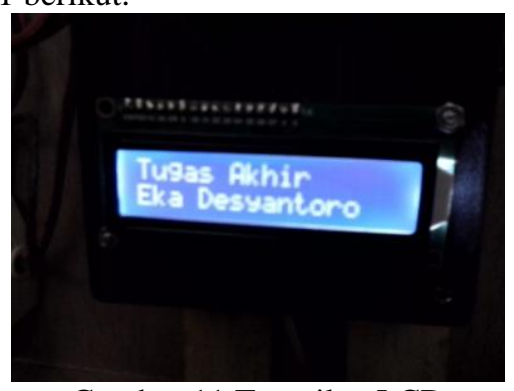

Gambar 11 Tampilan LCD

\subsection{PENGUJIAN SUBSISTEM PERANGKAT INPUT}

4.3.1 Pengujian Sensor PIR

Pengujian sensor PIR (Passive Infrared Receiver) bertujuan untuk mengetahui jarak dari sensor PIR dapat mendeteksi pergerakan manusia. Pengujian dilakukan dengan menghubungkan sensor PIR ke PORT B 0 mikrokontroller dan outputnya berupa LCD untuk menampilkan display ada manusia atau tidak. Jika terdeteksi adanya pergerakan manusia maka LCD akan menampilkan "H = 1", jika tidak terdeteksi pergerakan manusia maka LCD akan menampilkan " $\mathrm{H}$ $=0$ ". Percobaan dilakukan dari jarak $1-8$ meter dan hasilnya seperti yang ditunjukan pada tabel 1 .

Tabel 1 Pengujian Sensor PIR

\begin{tabular}{|c|c|c|}
\hline NO & $\begin{array}{c}\text { Jarak sensor PIR dan } \\
\text { manusia (meter) }\end{array}$ & $\begin{array}{c}\text { Tampilan } \\
\text { LCD }\end{array}$ \\
\hline 1 & 1 & $\mathrm{H}=1$ \\
\hline 2 & 2 & $\mathrm{H}=1$ \\
\hline 3 & 3 & $\mathrm{H}=1$ \\
\hline 4 & 4 & $\mathrm{H}=1$ \\
\hline 5 & 5 & $\mathrm{H}=1$ \\
\hline 6 & 6 & $\mathrm{H}=0$ \\
\hline 7 & 7 & $\mathrm{H}=0$ \\
\hline 8 & 8 & $\mathrm{H}=0$ \\
\hline
\end{tabular}




\subsubsection{Pengujian Sensor LM35}

Pengujian sensor LM35 bertujuan untuk mengetahui keakuratan nilai data dari sensor. Pengujian dilakukan dengan membandingkan hasil suhu dari sensor LM35 dan termometer ruangan. Hasil perbandingan suhu dari sensor LM35 dan termometer seperti yang ditunjukan tabel 2 .

Tabel 2 Pengujian Sensor suhu LM35

\begin{tabular}{|c|c|c|}
\hline $\begin{array}{c}\text { Menit } \\
\mathrm{Ke}\end{array}$ & $\begin{array}{c}\text { Data suhu } \\
\text { LM35 ( }{ }^{\circ} \text { celcius) }\end{array}$ & $\begin{array}{c}\text { Data suhu } \\
\left.\text { Termometer ( }{ }^{\circ} \text { celcius }\right)\end{array}$ \\
\hline 1 & 27 & 28 \\
\hline 2 & 26 & 28 \\
\hline 3 & 28 & 28 \\
\hline 4 & 25 & 28 \\
\hline 5 & 28 & 28 \\
\hline 6 & 28 & 28 \\
\hline 7 & 29 & 28 \\
\hline 8 & 28 & 28 \\
\hline 9 & 30 & 28 \\
\hline 10 & 28 & 28 \\
\hline 11 & 28 & 28 \\
\hline 12 & 27 & 28 \\
\hline 13 & 28 & 28 \\
\hline 14 & 28 & 28 \\
\hline 15 & 29 & 28 \\
\hline
\end{tabular}

Hasil pengujian pada tabel 2 menunjukan bahwa sensor mempunyai kesalahan $\pm 2{ }^{\circ}$ Celcius dari suhu yang ditunjukan oleh termometer hal ini di sebabkan karena LM35 sangat sensitive dengan keadaan sekitar. Selain suhu, angin juga dapat mempengaruhi hasil dari sensor suhu LM35.

\subsubsection{Pengujian Sensor LDR}

Pengujian sensor LDR digunakan untuk mendapatkan nilai digital hasil konversi dari nilai analog yang masuk pada ADC mikrokontroller. Nilai digital pada pengujian dapat dilihat pada display LCD. Tabel 3 berikut menunjukan nilai digital yang di dapat dari 4 keadaan pencahayaan yang berbeda.

Tabel 3 pengujian sensor LDR

\begin{tabular}{|c|l|c|}
\hline No & Keadaan Cahaya & $\begin{array}{c}\text { Konversi Nilai } \\
\text { Analog ke Digital } \\
\text { (bit / second) }\end{array}$ \\
\hline 1 & Terang & $600-750$ \\
\hline 2 & Agak Terang & $450-599$ \\
\hline 3 & Agak Gelap & $250-449$ \\
\hline 4 & Gelap & $0-245$ \\
\hline
\end{tabular}

\subsubsection{Pengujian Limit Switch}

Pengujian limit switch bertujuan untuk mengetahui limit switch masih bekerja dengan baik atau tidak. Pada sistem limit switch dipasang NC (Normally
Close) karena sesuai dengan kebutuhan sistem, dimana limit switch diletakan dipintu dalam kondisi tertekan saat pintu tertutup sehingga limit switch dalam keadaan tidak terhubung dan akan terhubung saat pintu terbuka.

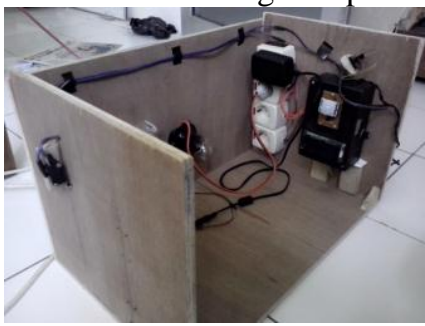

Gambar 12 limit switch pintu tertutup

Gambar 12 menunjukan sistem mati saat pintu tertutup karena limit switch dipasang secara NC (Normally Close) sehingga saat tertekan maka katup yang awalnya terhubung menjadi tidak terhubung sehingga menyebabkan sistem mati.

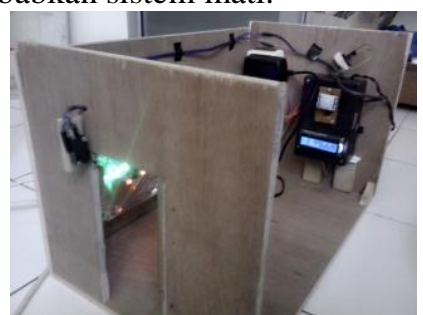

Gambar 13 limit switch pintu terbuka

Gambar 13 menunjukan sistem hidup karena pintu terbuka sehingga limit switch tidak tertekan yang menyebabkan katup pada limit switch terhubung karena di pasang secara NC (Normally Close).

\subsection{PENGUJIAN SUBSISTEM PERANGKAT OUTPUT}

Pengujian subsistem perangkat output pada sistem ini adalah pengujian relay yang terhubung ke stop kontak. Pengujian bertujuan untuk memastikan bahwa relay dapat bekerja dengan baik. Pengujian dilakukan dengan memprogram mikrokontroller untuk mengendalikan kontak relay dalam kondisi ON dan OFF. Berikut merupakan listing program untuk mengendalikan kontak relay yang terhubung ke PORT D 0-3 mikrokontroller.

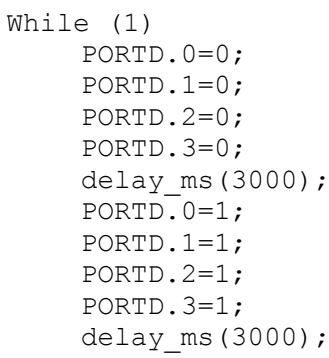

Dari listing program di atas relay akan "ON" selama 3 detik dan lampu pada stop kontak akan hidup seperti yang ditunjukan gambar 14 berikut. 


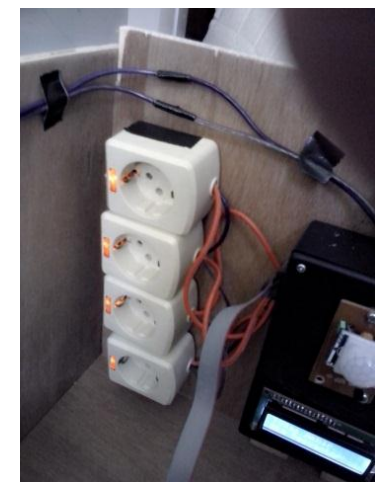

Gambar 14 kondisi saat relay on

kemudian setelah 3 detik maka relay akan "OFF" selama 3 detik dan lampu pada stop kontak akan mati seperti yang ditunjukan gambar 15 keadaan akan berulang terus relay $\mathrm{ON}$ dan OFF dengan selang waktu 3 detik.

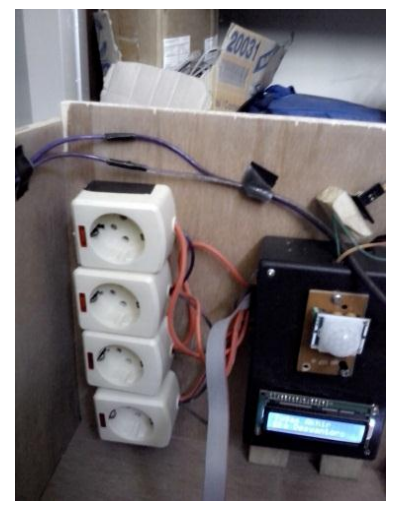

Gambar 15 kondisi saat relay off

\subsection{PENGUJIAN SISTEM KESELURUHAN}

Setelah dilakukan pengujian pada masingmasing perangkat input dan output, maka dilakukan pengujian keseluruhan sistem yaitu pengujian dengan menggabungkan seluruh perangkat input dan output menjadi suatu sistem yang dapat mengendalikan peralatan elektronik secara otomatis. Nilai setting sensor suhu di setting $22^{\circ} \mathrm{C}$

Tabel 4 menunjukan hasil pengujian perilaku sistem pengendali perlatan elektronik secara otomatis dari beberapa keadaan.

Tabel 4 pengujian sistem keseluruhan

\begin{tabular}{|c|c|c|c|c|c|c|c|}
\hline No & Sensor PIR & $\begin{array}{c}\text { Sensor } \\
\text { LM35 } \\
\left({ }^{\circ} \mathrm{C}\right)\end{array}$ & $\begin{array}{c}\text { Sensor } \\
\text { LDR } \\
\text { (bit / } \\
\text { second })\end{array}$ & $\begin{array}{c}\text { Stop } \\
\text { kontak } \\
1\end{array}$ & $\begin{array}{c}\text { Stop } \\
\text { kontak } \\
2\end{array}$ & $\begin{array}{c}\text { Stop } \\
\text { kontak 3 } \\
\text { (Lampu) }\end{array}$ & $\begin{array}{c}\text { Stop } \\
\text { kontak 4 } \\
\text { (pendingin } \\
\text { ruangan) }\end{array}$ \\
\hline 1 & $\begin{array}{l}\text { Mendeteksi } \\
\text { manusia }\end{array}$ & $>22$ & $>250$ & Nyala & Nyala & Mati & Nyala \\
\hline 2 & $\begin{array}{l}\text { Mendeteksi } \\
\text { manusia }\end{array}$ & $=22$ & $=250$ & Nyala & Nyala & Nyala & Nyala \\
\hline 3 & $\begin{array}{l}\text { Mendeteksi } \\
\text { manusia }\end{array}$ & $<22$ & $<250$ & Nyala & Nyala & Nyala & Mati \\
\hline 4 & $\begin{array}{l}\text { Tidak } \\
\text { mendeteksi } \\
\text { manusia }\end{array}$ & $>22$ & $>250$ & Nyala & Mati & Mati & Mati \\
\hline 5 & $\begin{array}{l}\text { Tidak } \\
\text { mendeteksi } \\
\text { manusia }\end{array}$ & $=22$ & $=250$ & Nyala & Mati & Mati & Mati \\
\hline 6 & $\begin{array}{l}\text { Tidak } \\
\text { mendeteksi } \\
\text { manusia }\end{array}$ & $<22$ & $<250$ & Nyala & Mati & Mati & Mati \\
\hline
\end{tabular}

\section{PENUTUP}

\subsection{KESIMPULAN}

Berdasarkan hasil pengujian dan analisis alat sistem pengendali peralatan elektronik dalam rumah secara otomatis dapat disimpulkan hal-hal sebagai berikut.

1. Sistem dapat mendeteksi keberadaan objek bergerak (dalam hal ini diasumsikan penghuni rumah / manusia), mengetahui suhu dan kondisi cahaya dalam rumah dan menampilkan nilai data sensor pada LCD.

2. Sensor LDR dapat mengetahui cahaya dalam rumah dalam keadaan gelap atau terang berdasarkan nilai konversi dari tegangan output sensor yang di ubah ke nilai digital yang ditunjukan pada LCD. Saat ada manusia dalam rumah dan output nilai konversi ke digital sensor LDR <=250 bit/second maka lampu hidup, sedangkan bila output nilai konversi ke digital sensor LDR > $250 \mathrm{bit} / \mathrm{second} \mathrm{maka} \mathrm{lampu} \mathrm{mati.}$

3. Pengujian kesalahan pembacaan sensor LM35 untuk suhu kurang lebih $2^{0} \mathrm{C}$. Saat ada manusia dalam rumah dan suhu $>=18^{\circ} \mathrm{C}$ maka pendingin ruangan hidup, ketika suhu $<18^{\circ} \mathrm{C}$ pendingin ruangan mati.

4. Apabila tidak ada aktivitas penghuni dalam rumah maka sistem dan peralatan elektronik tertentu dalam rumah mati.

\subsection{SARAN}

Berdasarkan hasil pengujian yang dilakukan pada sistem pengendali peralatan elektronik dalam rumah secara otomatis, dapat diberikan beberapa saran sebagai berikut.

1. Sistem dapat dikembangkan dalam pengendalian peralatan elektronik dapat dilakukan via bluetooth ataupun sms.

2. Dalam pengembangan penelitian sistem kedepannya dapat menggunakan sensor yang lebih presisi untuk mendeteksi suhu.

\section{DAFTAR PUSTAKA}

[1] Agung, Fajri Septia., dkk. 2009. Sistem Deteksi Asap Rokok Pada Ruangan Bebas Asap Rokok Dengan Keluaran Suara. Amik GI MDP. pp. $1-9$

[2] Assa'idah dan Y. Adnan. 2009. Investigasi Terhadap Kemampuan 2 Tipe ADC. Jurnal Penelitian Sains, vol. 12, pp. 1-5.

[3] Chamdun, Muhammad. 2014. "Sistem Keamanan Berlapis Pada Ruangan Menggunakan Rfid ( Radio Frequency Identification ) Dan Keypad Untuk Membuka Pintu Secara Otomatis". Universitas Diponegoro, Semarang.

[4] Melalolin, Ivan C. 2013. Rancang Bangun Brankas Pengaman Otomatis Berbasis 
Mikrokontroler AT89S52. Telekontran, vol. 1, no. 1.

[5] Muzaki, Ashita Shoman., dkk. 2010. Aplikasi Sensor Cahaya Untuk Alarm Anti Pencuri. $Q$ Journal.

[6] Nugroho, Agung. 2006. Metode Pengaturan Penggunaan Tenaga Listrik dalam upaya Penghematan bahan bakar Pembangkit dan Energi. Transmisi, pp. 45-51.

[7] Pamungkas, Danny Pramudyan. 2013. Troubleshooting Sistem Pengisian Honda Vario Techno 123 PGM-Fi. Universitas Negeri Semarang.

[8] Rantelino, Alan Prasetyo. 2014. Sistem Pembukaan Kunci Automatis Menggunakan Identifikasi Pola Ketukan. Universitas Diponegoro, Semarang.
[9] Setiandito, Yoga., dkk. 2011. Thermal Sensor LM35. Universitas Kristen Maranatha, Bandung.

[10] Sukendar, Aang., dkk. 2013. Pembuatan Sistem Otomasiuntuk Pengaturan Mekanisme Kerja Mesin Cetak Kerupuk Menggunakan Mikrokontroler ATMega. Jurnal Fema, vol. 1, pp. 31-38.

[11] Sumardi. 2013. Mikrokontroler Belajar AVR Mulai Dari Nol. Yogyakarta: Graha Ilmu.

[12] Sutono. Perancangan Sistem Aplikasi Otomatisasi Lampu Penerangan menggunakan Sensor Gerak dan Sensor Cahaya Berbasis Arduino UNO (ATMega 328). Maj. Ilm. UNIKOM, vol. 12 , no. 2, pp. 223-232.

[13] --, "Pyroelectric Infrared Radial Sensor." [Online]. Available: http://moderndevice.com/wpcontent/uploads/2010/11/33600005.pdf. Diakses pada 2 Maret 2015. 